\title{
Structural changes of the phytoplankton and epiphyton in an urban hypereutrophic reservoir
}

\author{
Mudanças estruturais do fitoplâncton e do epifíton em um reservatório urbano \\ hipereutrófico
}

\section{Lucineide Maria Santana $^{1 *}$ and Carla Ferragut ${ }^{2}$}

${ }^{1}$ Núcleo de Pesquisa em Ecologia, Programa de Pós-graduação em Biodiversidade Vegetal e Meio Ambiente, Instituto de Botânica, Av. Miguel Stéfano, 3687, Água Funda, CEP 04301-902, São Paulo, SP, Brazil

${ }^{2}$ Núcleo de Pesquisa em Ecologia, Instituto de Botânica, Av. Miguel Stéfano, 3687, Água Funda, CEP 04301-902, São Paulo, SP, Brazil

*e-mail: lucineidemsantana@yahoo.com.br

Cite as: Santana, L.M. and Ferragut, C. Structural changes of the phytoplankton and epiphyton in an urban hypereutrophic reservoir. Acta Limnologica Brasiliensia, 2016, vol. 28, e29.

Abstract: Aim: This study evaluated the temporal changes of phytoplankton and epiphyton structure and their relationships with limnological factors in an urban hypereutrophic reservoir (Rasgão Reservoir, Brazil). Methods: We collected water sample and phytoplankton in different depths at two sites (dam and near tributary input) in summer and winter 2010. Epiphyton on Salvinia spp. was sampled only at site near the tributary input. We determined limnological variables and structural attributes (species composition, density, biovolume, descriptors species, diversity) for both communities. Results: Phytoplankton density and epiphyton density and biovolume were higher in the winter (dry season), which occurred the higher nutrient concentrations and lower water flow. Chlorophyceae was dominant in the phytoplankton in both period and Cyanobacteria was the second most abundant class in the winter. In the epiphyton, Bacillariophyceae was dominant in the summer and Cyanobacteria in the winter. The increase in light availability and water flow can have provided high species richness and diversity in the summer. Conclusion: Temporal changes in the structure of phytoplankton and epiphyton on Salvinia were more related to increased nutrients availability (nitrogen and phosphorus) and flow variations in a hypereutrophic reservoir.

Keywords: algae community; plankton; periphyton; seasonality; urban pollution.

Resumo: Objetivo: Este estudo avaliou as mudanças temporais da estrutura do fitoplâncton e do epifíton e suas relaçôes com os fatores limnológicos em um reservatório urbano hipereutrófico (Reservatório Rasgão, Brasil). Métodos: Nós coletamos amostras de água e fitoplâncton em diferentes profundidades em dois locais (barragem e próximo da entrada do tributário) no verão e inverno de 2010. O epifíton em Salvinia spp. foi amostrado somente no local próximo da entrada do tributário. Nós determinamos as variáveis limnológicas e os atributos estruturais (composição de espécies, densidade, biovolume, espécies descritoras, diversidade) para ambas as comunidades. Resultados: A densidade do fitoplâncton e a densidade e o biovolume do epifíton foram maiores no inverno (estaçáo seca), no qual ocorreu as maiores concentraçóes de nutrientes e menor vazão. Chlorophyceae foi dominante no fitoplâncton em ambos os períodos e Cyanobacteria foi a segunda classe mais abundante no inverno. No epifíton, Bacillariophyceae foi dominante no verão e Cyanobacteria no inverno. $\mathrm{O}$ aumento da disponibilidade de luz e da vazáo pode ter favorecido a alta riqueza e diversidade de espécies no verão. Conclusão: As mudanças temporais na estrutura do fitoplâncton e do epifíton em Salvinia foram mais relacionadas com o aumento na disponibilidade de nutrientes (nitrogênio e fósforo) e às variaçôes na vazão em um reservatório hipereutrófico.

Palavras-chave: comunidade de algas; plâncton; perifíton; sazonalidade; poluição urbana. 


\section{Introduction}

Anthropogenic activities such as agriculture, urbanization and deforestation have caused excessive input of N, P, pesticides, metals, hormones and other pollutants in aquatic ecosystems (Smith \& Schindler, 2009). Cultural eutrophication has several negative consequences, including increased productivity and biomass of phytoplankton, periphyton and/or vascular plants; harmful algal blooms; decreasing in water transparency; and loss of biodiversity (Smith, 2003). Simultaneous assessment of phytoplankton and periphyton communities are extremely important for understanding the structure and dynamics of these communities and their relationships with environmental factors in hypereutrophic conditions. Besides, studies encompassing both communities might increase the knowledge of biodiversity and evaluation of environmental quality.

Phytoplankton and periphyton occupy different habitats, however compete for the same resources (light, nutrients) (Havens et al., 1996). Cyanobacteria blooms, for example, can reduce light availability to the periphyton, but the algae of this community can also show adaptations to shade (e. g. changes in pigments concentrations) (Borduqui \& Ferragut, 2012; Sánchez et al., 2013). On the other hand, periphyton can assimilate and retain nutrients of water column and obtain dissolved nutrients from living substrates, such as macrophytes (Vadeboncoeur \& Steinman, 2002). Thus, phytoplankton and periphyton are sensitive to environmental changes and can promptly respond to changes in nutrient availability even in eutrophic systems.

In reservoirs, the phytoplankton structure and dynamic are influenced by climatic, hydrological (e.g. water retention time) and limnological factors (particularly stratification and mixing) (Rangel et al., 2012; Nishimura et al., 2014). In addition to these factors, the periphyton structure is also influenced by availability and nature of the substratum (Vadeboncoeur \& Steinman, 2002). The macrophytes can have a strong influence on development of epiphyton, such as: providing area for colonization; modifying of light availability, serving both as sources and sinks for nutrients and allelochemicals; causing physical abrasion of algal assemblages; and providing habitat for grazers (Goldsborough \& Robinson, 1996).

Algal community acts in the functioning of lakes and reservoirs (Vadeboncoeur \& Steinman, 2002; Reynolds, 2006) and database about this primary producer is very important in restoration program of aquatic ecosystems. Thus, we assessed the structural attributes changes of phytoplankton and epiphyton in two climatic periods in an urban hypereutrophic reservoir (Rasgão Reservoir, São Paulo State, Brazil). Our main goal was to relate the structural characteristics of phytoplankton and epiphyton on natural substratum (Salvinia spp.) with environmental factors, in a highly degraded tropical reservoir.

\section{Material and Methods}

\subsection{Study area}

The Rasgão reservoir, situated in Pirapora do Bom Jesus city, is one of the reservoirs of the Pinheiros-Pirapora sub-basin, which is located at the downstream part of the Upper Tietê River basin, São Paulo State, Brazil (Figure 1). This reservoir is shallow (average depth: $6 \mathrm{~m}$ ) and has a surface area of $1.16 \mathrm{~km}^{2}$, volume of $4.9 \times 10^{7} \mathrm{~m}^{3}$ and average water retention time of 0.45 day (EMAE - Empresa Metropolitana de Águas e Energia). Rasgão was built in 1925 to increase electrical energy generation and supply São Paulo's city, which was undergoing a severe drought and industrial growth (Victorino, 2002; EMAE, 2015). The reservoir is hypereutrophic due the high load of organic matter and pollutants of untreated domestic and industrial sewage (CETESB, 2015). Studies evidenced that Rasgão reservoir presents bad water quality to aquatic fauna and flora (Water Quality Indices for Protection of Aquatic Life and Water Communities) (CETESB, 2009).

\subsection{Sampling design}

Water and phytoplankton samples were collected at site near the dam (Dam site) and at site near tributary input (TI site) in summer (10 March 2010) and winter (23 August 2010) (Figure 1). Water samples were collected in three depths at Dam site (euphotic zone: named as subsurface - $S$; middle - $\mathrm{M}$; and $1 \mathrm{~m}$ above the bottom - B) and in two depths at TI site (S and B). Epiphyton on Salvinia spp. was sampled only at site near tributary input (TI site) during the study period.

Water samples were gathered with a van Dorn sampler for determination of abiotic variables and phytoplankton analyses. Individuals $(n=2)$ of Salvinia spp., which did not present very young and senescent floating leaves, were selected randomly in the macrophyte stands. We removed the epiphyton on Salvinia modified leaves by washing with distilled water of known volume. The dry mass of 


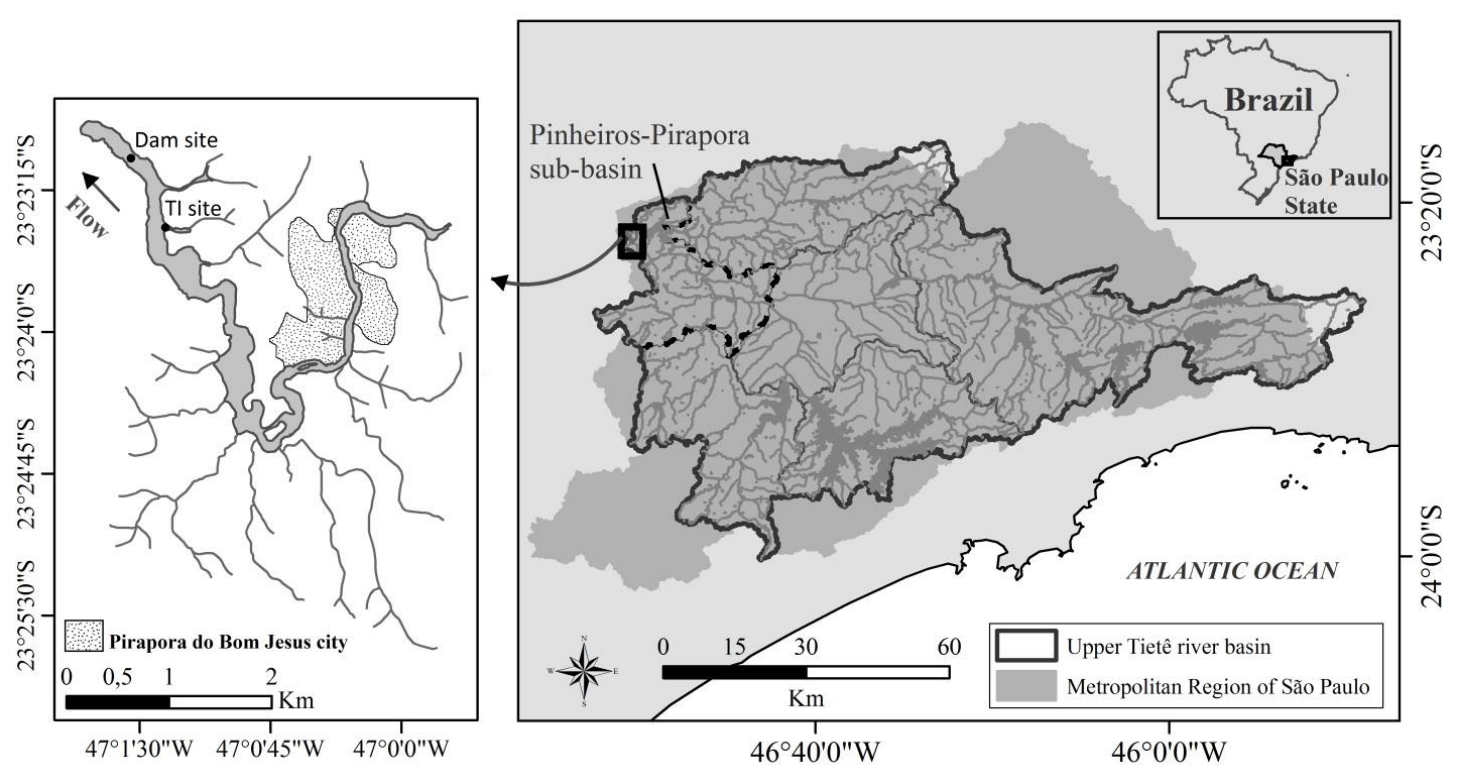

Figure 1. Study area and location of sampling sites.

the modified leaves was determined after drying for 24 hours at $70^{\circ} \mathrm{C}$. The epiphyton attributes (total density and biovolume) were expressed per mass unit.

\subsection{Analyzed variables and Trophic State Index}

Total accumulated rainfall and average daily air temperature were obtained from INMET (2015) network database. Daily volume and flow data were provided by EMAE (Empresa Metropolitana de Águas e Energia). These data were used to calculate the water retention time (average for each month).

Water temperature was measured by the multi-parameter probe (Eureka Amphibian). Water transparency was measured by Secchi disk and euphotic zone (Zeu) (Cole, 1983). Mixing zone (Zmix) was identified by the vertical temperature profile. The following variables were measured: $\mathrm{pH}$ (pHmeter Digimed), electric conductivity (Digimed), dissolved oxygen (DO) (Winkler modified by Golterman et al., 1978), alkalinity (Golterman \& Clymo, 1971), free $\mathrm{CO}_{2}$, nitrite $\left(\mathrm{N}-\mathrm{NO}_{2}\right)$ and nitrate $\left(\mathrm{N}-\mathrm{NO}_{3}\right)$ (Mackereth et al., 1978), ammonium $\left(\mathrm{N}-\mathrm{NH}_{4}\right)$ (Solorzano, 1969), soluble reactive phosphorus $\left(\mathrm{P}-\mathrm{PO}_{4}\right)$ and total dissolved phosphorus (TDP) (Strickland \& Parsons, 1960), total phosphorus (TP) and total nitrogen (TN) (Valderrama, 1981) and soluble reactive silica (SRS) (Golterman et al., 1978). Water samples for determination of dissolved nutrients were filtered under low pressure by glass-fiber filter (GF/F Whatman).
We determined phytoplankton chlorophyll $a$ (corrected for phaeophytin) concentration from a subsample filtered on glass-fiber filter (GF/F Whatman), following $24 \mathrm{~h}$ extraction with $90 \%$ ethanol (Sartory \& Grobbelaar, 1984).

We used chlorophyll $a$ and TP concentrations to calculate the Trophic State Index (TSI) (CETESB, 2015) for each site in both seasons.

\subsection{Biotic variables}

Phytoplankton and epiphyton samples were preserved with $4 \%$ formaldehyde for taxonomic analysis. Taxonomic identification was carried out using an optical binocular microscope (Zeiss Axioskop 2) with phase contrast and image capture. We used classification system of Van der Hoek et al. (1997) for class and specialized literature for specific levels (e. g. Komárek \& Foot, 1983; Komárek \& Anagnostidis, 2005; Metzeltin et al., 2005). Samples were oxidized using hydrogen peroxide (35-40\%) heated (CEN, 2003) and permanent diatom slides were mounted using Naphrax (database available from Acquased project).

Samples to quantitative analysis of phytoplankton and epiphyton were fixed with acetic lugol $0.5 \%$. Counting was made in an inverted microscope Zeiss Axio Observer D1, at a magnification of 400x, following Utermöhl (1958) method. Counting limits were the species rarefying curve and the minimum count of 100 individuals of the most abundant species. Epiphyton density was expressed in individuals per mass of dry-mass (ind $\mathrm{g}^{-1} \mathrm{DM}$ ). 
Phytoplankton $\left(\mu \mathrm{m}^{3} \mathrm{~L}^{-1}\right)$ and epiphyton $\left(\mu \mathrm{m}^{3} \mathrm{~g}^{-1}\right.$ DM) biovolume was estimated by multiplying each species' density by the mean volume of its individuals (cell, colony, coenobia, filament), considering, whenever possible, the dimension of at least 20 individuals of each species, following Hillebrand et al. (1999).

Algal species with relative density higher than or equal to $5 \%$ of the total density in each sample were considered descriptors and species with total density higher than or equal to $50 \%$ in each sample were considered dominant. Species richness (number of species per sample), diversity (Shannon-Winner's index: nats ind $^{-1}$ ) and dominance (Simpson's index) were calculated using algal density (Magurran, 2004).

\section{Results}

\subsection{Climate, hydrological, abiotic variables and TSI}

Considering total rainfall, two distinct periods were recognized during the year: rainy period (from October to March) and dry period (from April to September) (Figure 2). About the sampling months, in March 2010 (summer-rainy period) was registered $168 \mathrm{~mm}$ of rainfall and the minimum value $(0.2 \mathrm{~mm}$ ) occurred in August 2010 (winter-dry period). The average air temperature varied between $24.3^{\circ} \mathrm{C}$ (November 2009) and $12.5^{\circ} \mathrm{C}$ (June 2010). Despite water retention time have been lower than one day throughout the year, we observed higher value in the winter than in the summer (0.51 and 0.27 day, respectively). The flow in the winter was two times lower than in the summer (93.3 and $197.5 \mathrm{~m}^{3} \mathrm{~s}^{-1}$, respectively).

Isothermy was observed at Dam site in the summer and winter and a thermal stratification at TI site. Water transparency and euphotic zone were about $50 \%$ higher in the summer than in the winter, however the values were very low in regarding to Zmax of sampling sites (Table 1).

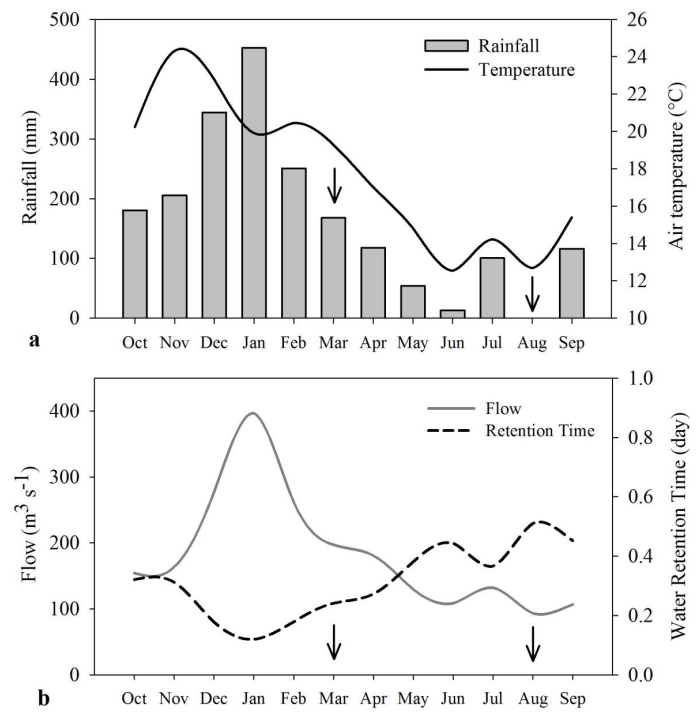

Figure 2. Total accumulated rainfall and average monthly air temperature (a) and average flow and water retention time (b) of the Rasgáo reservoir (period: October 2009 to September 2010). The arrows indicate the sampling months.

Table 1. Limnological variables in an urban hypereutrophic reservoir during the study period (Zmax: maximum depth; S: subsurface, $\mathrm{M}$ : middle, $\mathrm{B}$ : bottom; DIN: dissolved inorganic nitrogen $=\mathrm{N}-\mathrm{NO}_{2}+\mathrm{N}-\mathrm{NO}_{3}+\mathrm{N}-\mathrm{NH}_{4}$ ).

\begin{tabular}{|c|c|c|c|c|c|c|c|c|c|c|}
\hline \multirow{2}{*}{ Site } & \multicolumn{5}{|c|}{ Summer } & \multicolumn{5}{|c|}{ Winter } \\
\hline & Dam & & & $T I$ & & Dam & & & $T I$ & \\
\hline Zmax (m) & 8.5 & & & 3.0 & & 9.0 & & & 3.5 & \\
\hline Zmix (m) & 8.5 & & & 0.5 & & 9.0 & & & 0.5 & \\
\hline Water transparency $(\mathrm{m})$ & 0.44 & & & 0.50 & & 0.25 & & & 0.26 & \\
\hline Zeu (m) & 1.19 & & & 1.35 & & 0.68 & & & 0.70 & \\
\hline Layer & $S$ & $M$ & $B$ & $S$ & $B$ & $S$ & $M$ & $B$ & $S$ & $B$ \\
\hline Temperature $\left({ }^{\circ} \mathrm{C}\right)$ & 24.7 & 24.4 & 24.4 & 24.2 & 22.5 & 20.7 & 20.1 & 20.0 & 19.8 & 17.0 \\
\hline $\mathrm{DO}\left(\mathrm{mg} \mathrm{L}^{-1}\right)$ & 3.5 & 3.5 & 3.5 & 1.2 & 0.4 & 0.3 & 0.1 & 0.1 & 0.5 & 0.2 \\
\hline $\mathrm{pH}$ & 7.2 & 7.4 & 7.3 & 7.3 & 7.3 & 7.2 & 7.4 & 7.3 & 7.3 & 7.3 \\
\hline Conductivity $\left(\mu \mathrm{S} \mathrm{cm}^{-1}\right)$ & 191.0 & 202.0 & 203.0 & 181.2 & 165.0 & 575.6 & 575.0 & 574.8 & 578.7 & 584.2 \\
\hline Alkalinity (mEq L-1) & 2.1 & 2.0 & 1.9 & 1.9 & 1.8 & 3.2 & 3.0 & 3.1 & 3.0 & 3.0 \\
\hline Free $\mathrm{CO}_{2}\left(\mathrm{mg} \mathrm{L}^{-1}\right)$ & 5.8 & 4.9 & 8.3 & 4.8 & 5.8 & 21.3 & 12.8 & 17.3 & 16.5 & 18.6 \\
\hline DIN $\left(\mathrm{mg} \mathrm{L}^{-1}\right)$ & 10.7 & 11.4 & 10.9 & 9.5 & 7.1 & 25.2 & 25.9 & 26.4 & 27.1 & 24.5 \\
\hline $\mathrm{TN}\left(\mathrm{mg} \mathrm{L}^{-1}\right)$ & 22.2 & 22.3 & 21.8 & 19.5 & 15.1 & 28.0 & 27.6 & 28.4 & 29.3 & 26.1 \\
\hline $\mathrm{P}-\mathrm{PO}_{4}\left(\mathrm{mg} \mathrm{L}^{-1}\right)$ & 0.3 & 0.3 & 0.4 & 0.2 & 0.2 & 1.1 & 1.1 & 1.2 & 1.3 & 1.3 \\
\hline $\operatorname{TDP}\left(\mathrm{mg} \mathrm{L}^{-1}\right)$ & 0.4 & 0.4 & 0.4 & 0.3 & 0.2 & 1.1 & 1.2 & 1.2 & 1.3 & 1.3 \\
\hline $\mathrm{TP}\left(\mathrm{mg} \mathrm{L}^{-1}\right)$ & 0.7 & 0.6 & 0.6 & 0.5 & 0.3 & 1.8 & 1.7 & 1.8 & 2.0 & 1.6 \\
\hline SRS $\left(\mathrm{mg} \mathrm{L}^{-1}\right)$ & 4.9 & 4.9 & 4.9 & 4.6 & 4.2 & 7.1 & 7.0 & 7.2 & 7.0 & 6.7 \\
\hline NT: PT molar ratio & 75.2 & 80.3 & 76.9 & 93.8 & 106.5 & 35.1 & 36.8 & 34.1 & 32.5 & 36.7 \\
\hline
\end{tabular}


The vertical distribution of temperature, DO, DIN, TN and TP concentration identified stratified thermal-chemical gradient at TI site and homogeneous at Dam site (Table 1). The highest conductivity, alkalinity, free $\mathrm{CO}_{2}, \mathrm{DIN}, \mathrm{TN}$ and SRS concentrations were found in the winter in both sites. The $\mathrm{P}_{-} \mathrm{PO}_{4}, \mathrm{TDP}$ and TP concentrations were 3.0 times higher in the winter than in the summer at Dam site and about 4.5 - 6.5 times higher at TI site. In contrast, the highest TN:TP molar ratio was found in the summer. Rasgão reservoir presented TSI values into eutrophic state in the summer (Dam: 61.8, TI: 62.5) and hypereutrophic in the winter (Dam: 67.6, TI: 67.6).

\subsection{Phytoplankton and epiphyton}

Phytoplankton total density and biovolume tended to decrease from the subsurface to the bottom (Figure 3a-3b). Higher values of phytoplankton total density occurred in the winter, period in which the density was about 2.0 times higher than in the summer. Epiphyton total density and biovolume were about 6.0 and 8.0 times higher in the winter than in the summer (Figure 3c-3d).

Phytoplankton presented 86 taxa, which were distributed into 7 taxonomic groups: Bacillariophyceae, Chlorophyceae, Cyanobacteria, Cryptophyceae, Dinophyceae, Euglenophyceae and Zygnemaphyceae. Chlorophyceae and Euglenophyceae showed the higher number of taxa: 41 and 22, respectively. For the epiphyton, we identified 60 taxa of algae distributed into 5 groups: Bacillariophyceae, Chlorophyceae, Cyanobacteria, Euglenophyceae and Oedogoniophyceae. Chlorophyceae contributed to 24 taxa for epiphyton structure, followed by Bacillariophyceae (18 taxa). We found that 19 taxa (31\%) and 6 taxa (13\%) were common between phytoplankton (subsurface
Phytoplankton

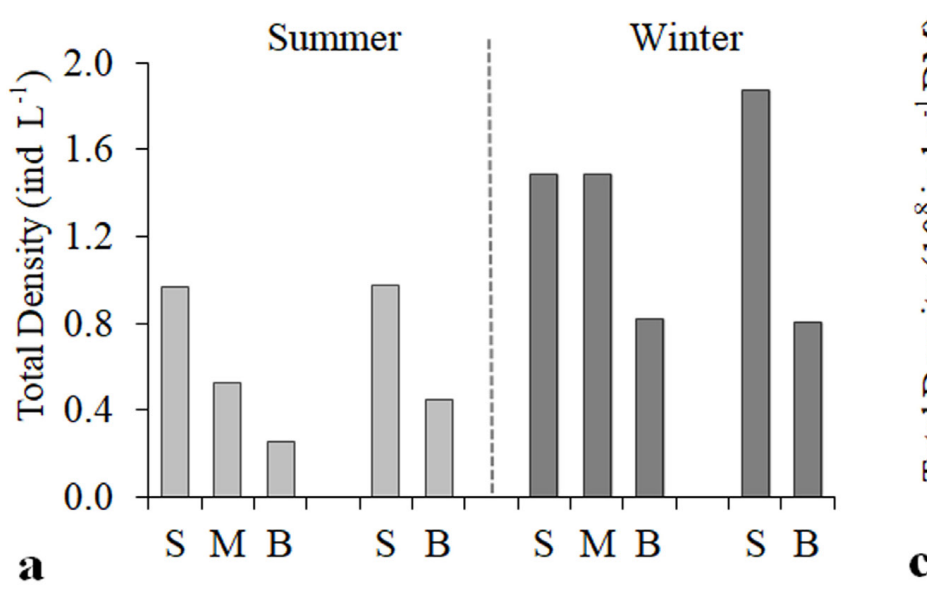

Epiphyton

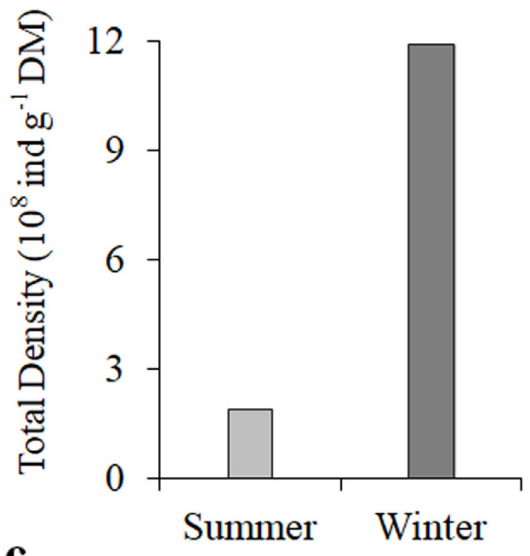

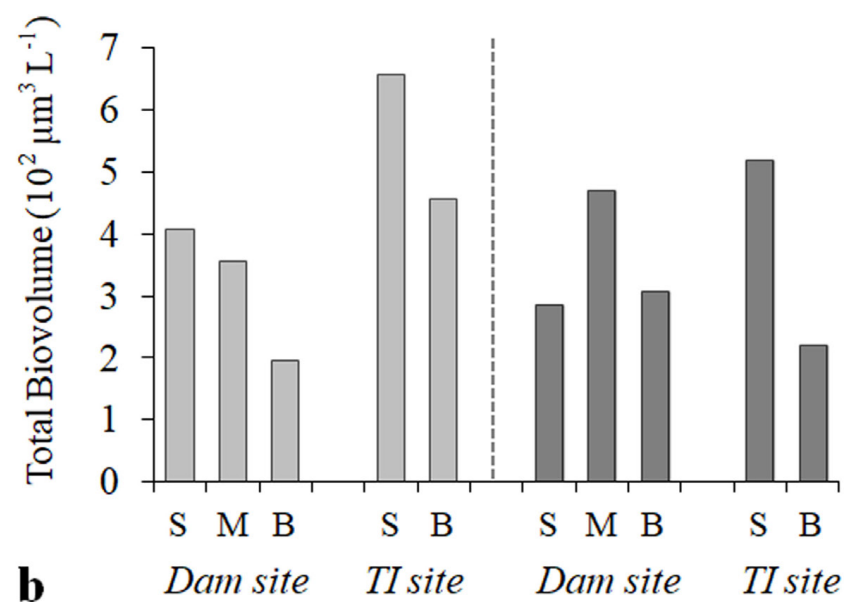

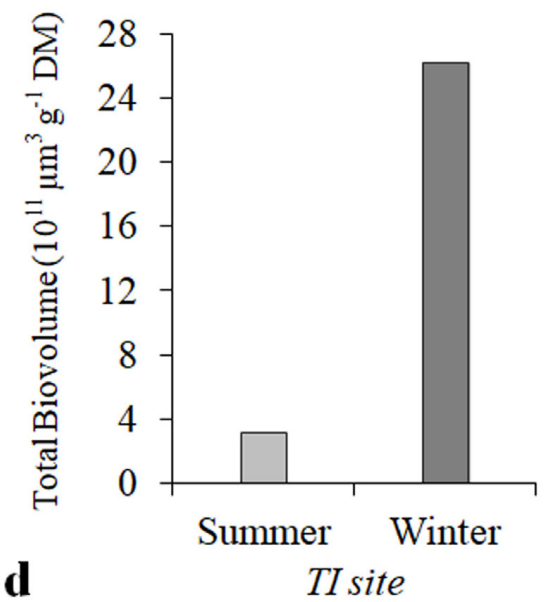

Figure 3. Phytoplankton (a, b) and epiphyton (c, d) total density and biovolume in an urban hypereutrophic reservoir during the study period (S: subsurface, M: middle, B: bottom). 
- TI site) and epiphyton in the summer and winter, respectively, mostly comprised species of Chlorophyceae.

Regarding to relative density of phytoplankton classes, Chlorophyceae was dominant in both seasons. In the winter, Cyanobacteria was the second most abundant class in the phytoplankton (26.4-31.0\%), especially at Dam site (Figure 4a). In the epiphyton, Bacillariophyceae was dominant in the summer and Cyanobacteria dominated in the winter (Figure 4c).

Phytoplankton descriptor species with the highest relative density was Chlorella vulgaris Beyerinck, which contributed with $46 \%$ to $74 \%$ of total density in both sites and seasons. Oocystis spp., Chlamydomonas sp. 1, Monoraphidium cf. tortile (W.West \& G.S.West) Komárková-Legnerová and Cyclotella meneghiniana Kützing also presented high contribution in the summer and Synechocystis aquatilis Sauvageau, Synechococcus cf. nidulans (Pringsheim) Komárek and Chlamydomonas sp. 2 were abundant in the winter (Figure $4 \mathrm{~b}$ ). In the epiphyton, Cyclotella meneghianiana represented $27 \%$ of total density in the summer, followed by Chlorella vulgaris (8\%) and another diatoms species [Nitzschia palea (Kützing) Smith and Navicula antonii Lange-Bertalot, both 7\%]. Geitlerinema amphibium (C. Agardh ex Gomont) Anagnostidis was the most abundant species in the winter (39\%), followed by diatoms species (Nitzschia palea, 17\% and Pinnularia cf. gibba Ehrenberg, 9\%) and Phormidium formosum (Bory ex Gomont) Anagnostidis \& Komárek (8\%) (Figure 4d).

The phytoplankton presented greater species richness in the summer, mainly at TI site. The higher diversity and lower dominance indices were verified at Dam site (bottom) and TI site in the summer and at Dam site in the winter (Figure 5a-5c). Regarding to the epiphyton, the greater richness and diversity occurred in the summer. In general, epiphyton showed the higher diversity $\left(2.0-2.8\right.$ nats ind $\left.{ }^{-1}\right)$ and lower dominance (0.1-0.2) (Figure 5d-5f).

\section{Discussion}

Our results showed that environmental conditions were more favorable to development of phytoplankton and epiphyton in the winter

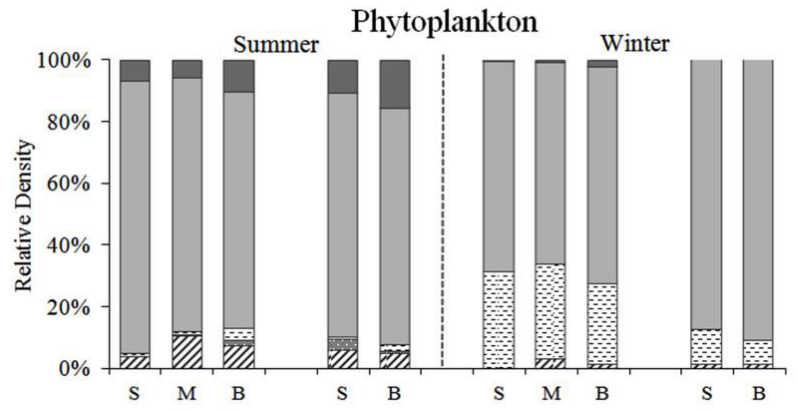

a

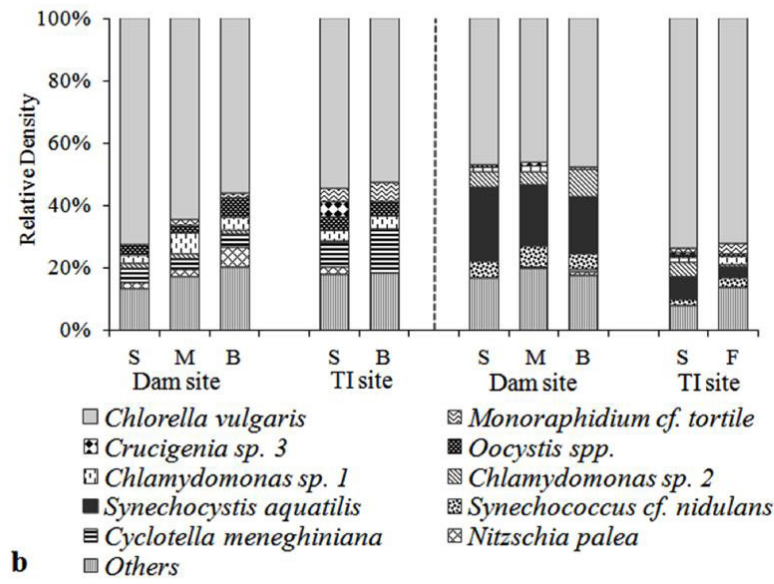

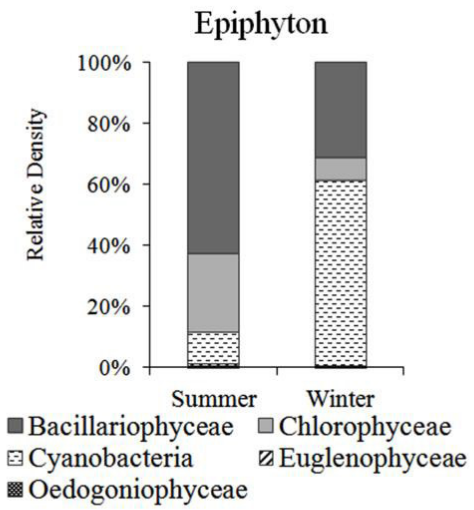

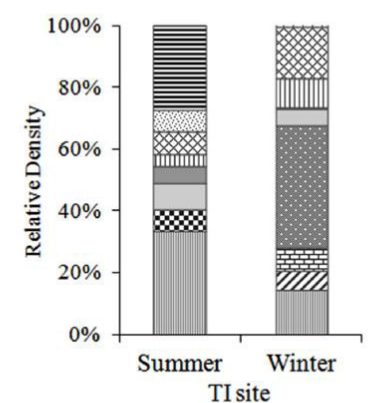

ECyclotella meneghiniana 图 Navicula antonii $\otimes$ Nitzschia palea $\quad$ Pinnularia cf. gibba

$\square$ Pinnularia acrosphaeria $\square$ Chlorella vulgaris

Geitlerinema amphibium Heteroleibleinia sp.

d

Figure 4. Phytoplankton $(\mathbf{a}, \mathbf{b})$ and epiphyton $(\mathbf{c}, \mathbf{d})$ classes density and descriptors species in an urban hypereutrophic reservoir during the study period (S: subsurface, M: middle, B: bottom). 

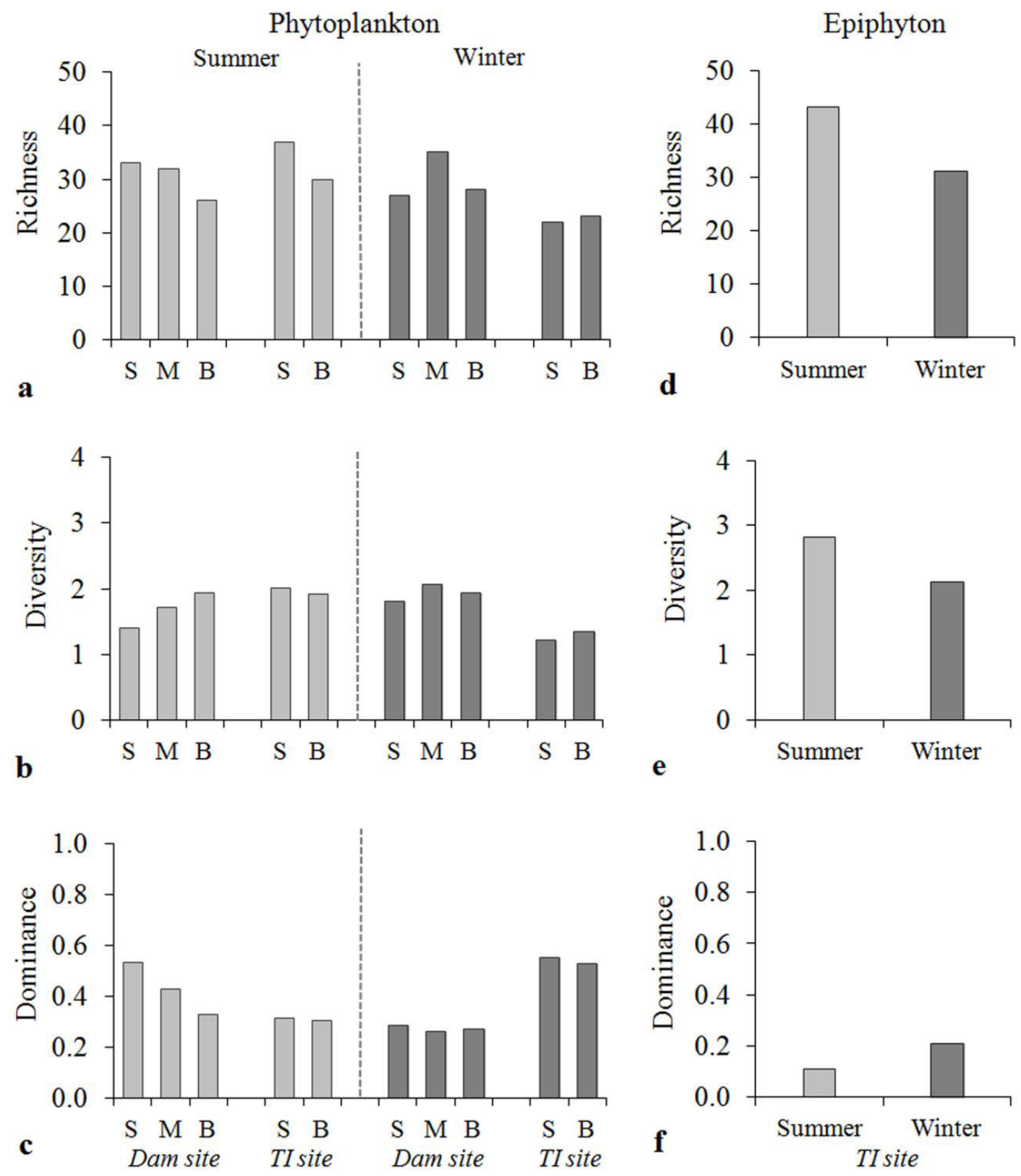

Figure 5. Species richness, diversity and dominance of phytoplankton (a-c) and epiphyton (d-f) in an urban hypereutrophic reservoir during the study period (S: subsurface, M: middle, B: bottom).

than in the summer in the studied hypereutrophic reservoir. Most studies about phytoplankton structure show that physical processes of stratification and mixing are driving factors in tropical reservoirs (e. g. Fonseca \& Bicudo, 2008; Becker et al., 2009). However, stratification and mixing processes were not considered determinants factors to phytoplankton structure during the study period, because, despite the difference in thermal profile between sites, we recorded similar total density and dominance of same classes and species within sites in both periods. In contrast, resources availability (light and nutrient) was different between the two seasons, especially orthophosphate concentration that was about 4 times higher in the winter than in the summer. Despite the high P (P-PO4, TDP) and DIN availability in the winter, the water transparency was low, which would be unfavorable for increasing algal biomass (density and biovolume). However, the flow was greatly reduced in the winter, which lead higher nutrient concentrations, mainly dissolved $\mathrm{N}$ and $\mathrm{P}$. In the winter, the reservoir received a smaller volume of water to dilute the high load of organic matter and nutrients of the wastewater from upstream cities 
(CETESB, 2015). In relation to the epiphyton, other studies also reported greater development of community in the winter (dry season) in reservoirs of different trophic state, particularly, in lower phytoplankton biomass (Borduqui \& Ferragut, 2012) or less macrophyte coverage conditions (Souza et al., 2015). Our findings showed that the hydrological variables (mainly flow) and dissolved nutrient supply were determinants factors of algal biomass changes in the plankton and epiphyton in reservoir during the study period.

Phytoplankton presented dominance of small coccoid green algae in all depths of sampling sites (near and far from the dam) in the summer and winter, mainly Chlorella vulgaris. This species is commonly found in similar environmental conditions of the reservoir studied (hypereutrophic). Chlorella vulgaris comprises the group of nanoplanktonic green algae, which are opportunists and good competitors for resources in eutrophic conditions with low light availability and short water retention time, as in the present study (Happey-Wood, 1988). Studies have related C. vulgaris in eutrophic-hypereutrophic reservoirs (Padisák et al., 2009) and reservoirs storing wastewater effluent (Dor et al., 1987). Chlorella species have efficient adaptive strategies for living in hypereutrophic condition, such as high surface-volume ratio, high growth rate (Happey-Wood, 1988) and capacity to carry out heterotrophy and symbiosis with bacteria (Lananan et al., 2014). Another abundant nanoplanktonic species in the winter was Synechocistis aquatilis, which is also good competitor in turbid waters and has been dominant in eutrophic-hypereutrophic reservoirs (Fernández et al., 2012).

Epiphyton structure on Salvinia spp. was characterized by dominance of Bacillariophyceae in the summer and Cyanobacteria in the winter. Within the descriptors species in the summer, we found high abundance of Cyclotella meneghiniana, which has been reported in eutrophic and hypereutrophic systems and rich in organic matter, being considered species resistant to pollution (Romo \& Miracle, 1994; Van Dam et al., 1994; Lobo et al., 2010). The periphytic diatoms reduced their contribution in the community in the winter, but $N$. palea showed high representativeness. This species has great affinity to water with low dissolved oxygen and elevated $\mathrm{P}$ concentrations (Van Dam et al., 1994; Lobo et al., 2010), corresponding the hypereutrophic conditions of the reservoir studied. Environmental conditions in the winter were favorable to the high abundance of filamentous cyanobacteria in the epiphyton, particularly Geitlerinema amphibium, which can explain the high biovolume in this season. G. amphibium is widespread and usually found in phytoplankton, but in epiphyton is associated with stagnant water (Komárek \& Anagnostidis, 2005). This species was found in eutrophic reservoirs (Oliveira et al., 2015) and shallow hypereutrophic lake (Romo \& Miracle, 1994) and presents adaptability to shade and tolerance to high turbidity (Padisák et al., 2009). The adaptive characteristics of $G$. amphibium can also have ensured the success in periphytic habitat.

Considering the TI site (site where it was collected both communities), our findings showed that the phytoplankton and epiphyton differed in relation to dominant classes and descriptors species. However, in the summer the number of common species between phytoplankton and epiphyton, as well species richness, was higher than in the winter. Probably, high water flow in the summer, due to greater precipitation, can have favored species exchanges between communities. Furthermore, the phytoplankton and epiphyton communities lose their specificity for habitats with eutrophication (Moss, 1981). Within these common species, most was Chlorophyceae (e.g. Monoraphidium spp.), which is frequently found in tropical reservoirs, in different habitats and trophic state (Ferragut et al., 2005; Chellapa et al., 2008). In the summer also occurred higher diversity and lower dominance of species, which reflected in higher richness and common species, mostly in the epiphyton. Another important aspect was the occurrence of greater water transparency and Zeu in the summer, so the higher light availability can also have provided the coexistence of a greater number of species.

We conclude that the temporal changes in the structure of phytoplankton and epiphyton on Salvinia were more related to the increased nutrient availability ( $\mathrm{N}$ and $\mathrm{P}$ ) and flow variations. The increase in light availability and water flow provided the rising of species diversity and richness in phytoplankton and epiphyton, but the increased nutrient availability and reduced flow favored a greater algal density and biovolume (Figure 6). Based on phytoplankton and epiphyton structure, we verified a decreasing of algal richness and diversity with the deteriorating in water quality and decreased flow in the winter in a hypereutrophic reservoir. 


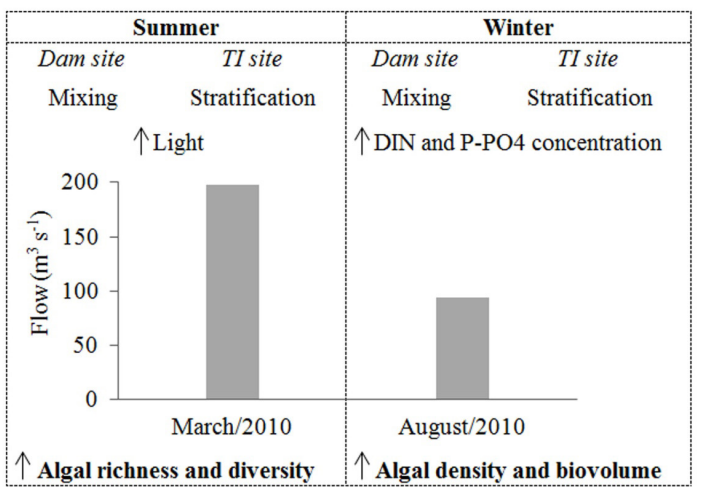

Figure 6. Schematic diagram summarizing the main changes in abiotic and biotic variables between seasons in an urban hypereutrophic reservoir.

\section{Acknowledgements}

We acknowledge FAPESP (Fundação de Amparo à Pesquisa do Estado de São Paulo) for a doctoral fellowship granted for LMS (Process $\mathrm{n}^{\circ}$ 2011/24000-4). This study was carried out within the framework of the AcquaSed project (Baseline diagnosis and reconstruction of anthropogenic impacts in the Guarapiranga Reservoir, focusing on sustainability in water supply and water quality management in reservoirs of the Upper Tietê and surrounding basins) supported by funds from FAPESP (AcquaSed Project, no 2009/53898-9). We thank especially Dra. Angélica C. Righetti da Rocha for her help and efforts in the limnological and diatom database. We deeply appreciate the valuable assistance of personnel from the Secretaria de Meio Ambiente do Município de Pirapora do Bom Jesus for their valuable logistical support during the fieldwork. We thank all the students and technicians from the Department of Ecology, Institute of Botany, involved in the field and laboratory work.

\section{References}

BECKER, V., HUSZAR, V.L.M. and CROSSETTI, L.O. Responses of phytoplankton functional groups to the mixing regime in a deep subtropical reservoir. Hydrobiologia, 2009, 628, 137-151. http://dx.doi. org/10.1007/s10750-009-9751-7.

BORDUQUI, M. and FERRAGUT, C. Factors determining periphytic algae succession in a tropical hypereutrophic reservoir. Hydrobiologia, 2012, 683(1), 109-122. http://dx.doi.org/10.1007/s10750011-0943-6.

CHELLAPA, N.T., BORBA, J.M. and ROCHA, O. Phytoplankton community and physicalchemical characteristics of water in the public reservoir of Cruzeta, RN, Brazil. Brazilian Journal of Biology = Revista Brasileira de Biologia, 2008, 68(3), 477-494. http://dx.doi.org/10.1590/S151969842008000300004 . PMid:18833468.

COLE, G. Textbook of limnology. 3rd ed. London: The C.V. Mosby Co., 1983.

COMITÉ EUROPÉEN DE NORMALISATION - CEN. Water quality - Guidance standard for the routine sampling and pretreatment of benthic diatoms from rivers. Geneva: CEN, 2003.

COMPANHIA DE TECNOLOGIA DE SANEAMENTO AMBIENTAL - CETESB. Relatório de qualidade das águas interiores do estado de São Paulo 2008. São Paulo: CETESB, 2009, 528 p. Technical Report.

COMPANHIA DE TECNOLOGIA DE SANEAMENTO AMBIENTAL - CETESB. Qualidade das águas superficiais no estado de São Paulo 2014. São Paulo: CETESB, 2015, 520 p. Technical Report.

DOR, I., SCHECHTER, H. and BROMLEY, H.J. Limnology of a hypertrophic reservoir storing wastewater effluent for agriculture at Kibbutz Na an, Israel. Hydrobiologia, 1987, 150, 225-241. http:// dx.doi.org/10.1007/BF00008705.

EMPRESA METROPOLITANA DE ÁGUAS E ENERGIA - EMAE. Histórico [online]. São Paulo: EMAE: 2015 [viewed 10 Sept. 2015]. Available from: http://www.emae.com.br/conteudo.asp?id=Historico

FERNÁNDEZ, C., PARODI, E.R. and CÁCERES, E.J. Phytoplankton structure and diversity in the eutrophic-hypereutrophic reservoir Paso de las Piedras, Argentina. Limnology, 2012, 13, 13-25. http://dx.doi.org/10.1007/s10201-011-0347-3.

FERRAGUT, C., LOPES, M.R.M., BICUDO, D.C., BICUDO, C.E.M. and VERCELLINO, I.S. Ficoflórula perifítica e planctônica (exceto Bacillariophyceae) de um reservatório oligotrófico raso (Lago do IAG, São Paulo). Hoehnea, 2005, 32(2), 137-184.

FONSECA, B.M. and BICUDO, C.E.M. Phytoplankton seasonal variation in a shallow stratified eutrophic reservoir (Garças Pond, Brazil). Hydrobiologia, 2008, 600, 267-282. http://dx.doi.org/10.1007/s10750007-9240-9.

GOLDSBOROUGH, G. and ROBINSON, G.G.C. Pattern in Wetlands. In R.J. STEVENSON, M.L. BOTHWELL and R.L. LOWE, eds. Algal ecology: freshwater benthic ecosystems. San Diego: Academic Press, 1996, pp. 77-117.

GOLTERMAN, H.L. and CLYMO, R.S. Methods for chemical analysis of freshwaters. Oxford: Blackwell Scientific Publications, 1971. International Biological Programmer.

GOLTERMAN, H.L., CLYMO, R.S. and OHMSTAD, M.A.M. Methods for physical and chemical analysis 
of freshwaters. 2nd ed. Oxford: Blackwell Scientific Publications, 1978. International Biological Program.

HAPPEY-WOOD, C.M. Ecology of freshwater planktonic green algae. In C.D. SANDGREN, ed. Growth and reproductive strategies of freshwater phytoplankton. Cambridge: Cambridge University Press, 1988, pp. 103-133.

HAVENS, K.E., EAST, T.L., MEEKER, R.H., DAVIS, W.P. and STEINMAN, A.D. Phytoplankton and periphyton responses to in situ experimental nutrient enrichment in a shallow subtropical lake. Journal of Plankton Research, 1996, 18(4), 551-566. http:// dx.doi.org/10.1093/plankt/18.4.551.

HILLEBRAND, H., DÜRSEKEN, C.D., KIRSCHIEL, D., POLLINGHER, U. and ZOHARY, T. Biovolume calculation for pelagic and benthic microalgae. Journal of Phycology, 1999, 35, 403-424. http:// dx.doi.org/10.1046/j.1529-8817.1999.3520403.x.

INSTITUTO NACIONAL DE METEROLOGIA INMET. Banco de Dados Meteorológicos para Ensino e Pesquisa (BDMEP) [online]. Brasília: INMET, 2015. [viewed 30 Aug. 2015]. Available from: http://www. inmet.gov.br/portal/index.php?r=bdmep/bdmep

KOMÁREK, J. and ANAGNOSTIDIS, K. Cyanoprokaryota 2: Oscillatoriales. In B. BÜNDEL, L. KRIENITZ, G. GÄRTNER and M. SCHAGERL, eds. Süsswasserflora von Mitteleuropa. Heidelberg: Elsevier/Spektrum, 2005.

KOMÁREK, J. and FOOT, B. Chlorophyceae (Grünalgen), Ordung: Chlorococcales. In G. HUBER-PESTALOZZI, ed. Das phytoplankton des Sübwassers: Systematik und Biologie. Stuttgart: E. Schweizerbart'sche Verlagsbuchlandlung (Nägele u. Obermiller), 1983, pp. 1-1044.

LANANAN, F., HAMID, S.H.A., DIN, W.N.S., ALI, N., KHATOON, H., JUSOH, A. and ENDUT, A. Symbiotic bioremediation of aquaculture wastewater in reducing ammonia and phosphorus utilizing Effectiv Microorganism (EM-1) and microalgae (Chlorella sp.). International Biodeterioration of Biodegradation, 2014, 95, 127-134. http://dx.doi. org/10.1016/j.ibiod.2014.06.013.

LOBO, E.A., WETZEL, C.E., ECTOR, L., KATOB, K., BLANCO, S. and MAYAMA, S. Response of epilithic diatom communities to environmental gradients in subtropical temperate Brazilian rivers. Limnetica, 2010, 29(2), 323-340.

MACKERETH, F.J.H., HERON, J. and TALLING, J.F. Water analysis: some revised methods for limnologists. Cumbria: Freshwater Biological Association, 1978.

MAGURRAN, A.E. Measuring biological diversity. Oxford: Blackwell Science, 2004.

METZELTIN, D., LANGE-BERTALOT, H. and GARCIA-RODRIGUEZ, F. Diatoms of Uruguay compared with other taxa from South America and elsewhere. In H. LANGE-BERTALOT, ed.
Iconographia Diatomologica. Ruggell: Gantner Verlag K.G., 2005, pp. 1-736. vol. 15.

MOSS, B. The composition and ecology of periphyton communities in freshwaters. II: inter-relationships between water chemistry, phytoplankton populations and periphyton populations in a shallow lake and associated experimental reservoirs ('Lund tubes'). British Phycological Journal, 1981, 16, 59-76.

NISHIMURA, P.Y., MEIRINHO, P.A., MOSCHINICARLOS, V. and POMPEO, M.L.M. Does the plankton community follow the horizontal water quality heterogeneity in a tropical urban reservoir (Guarapiranga reservoir, São Paulo, Brazil)? Limnetica, 2014, 33(2), 263-280.

OLIVEIRA, F.H.P.C., SILVA, J.D.B., COSTA, A.N.S.F., RAMALHO, W.P., MOREIRA, C.H.P. and CALAZANS, T.L.S. Cyanobacteria community in two tropical eutrophic reservoirs in northeastern Brazil. Acta Scientiarum. Biological Sciences, 2015, 37(2), 169-176. http://dx.doi.org/10.4025/ actascibiolsci.v37i2.26418.

PADISÁK, J., CROSSETTI, L.O. and NASELLIFLORES, L. Use and misuse in the application of the phytoplankton functional classification: a critical review with updates. Hydrobiologia, 2009, 621, 1-19. http://dx.doi.org/10.1007/s10750-008-9645-0.

RANGEL, L.M., SILVA, L.H.S., ROSA, P., ROLAND, F. and HUSZAR, V.L.M. Phytoplankton biomass is mainly controlled by hydrology and phosphorus concentrations in tropical hydroelectric reservoirs. Hydrobiologia, 2012, 693, 13-28. http://dx.doi. org/10.1007/s10750-012-1083-3.

REYNOLDS, C.S. Phytoplankton ecology and aquatic ecosystems: mechanisms and management. In C.S. REYNOLDS, ed. Ecology of Phytoplankton. New York: Cambridge University Press, 2006, pp. $387-$ 436.

ROMO, S. and MIRACLE, M.R. Population dynamics and ecology of subdominant phytoplankton species in a shallow hypertrophic lake (Albufera of Valencia, Spain). Hydrobiologia, 1994, 273, 31-56. http:// dx.doi.org/10.1007/BF00126767.

SÁNCHEZ, M.L., PÉREZ, G.L., IZAGUIRRE, I. and PIZARRO, H. Influence of underwater light climate on periphyton and phytoplankton communities in shallow lakes from the Pampa plain (Argentina) with contrasting steady states. Journal of Limnology, 2013, 72(1), 62-78. http://dx.doi.org/10.4081/ jlimnol.2013.e6.

SARTORY, D.P. and GROBBELAAR, J.U. Extraction of chlorophyll a from freshwater phytoplankton for spectrophotometric analysis. Hydrobiologia, 1984, 114, 177-187. http://dx.doi.org/10.1007/ BF00031869.

SMITH, V.H. and SCHINDLER, D.W. Eutrophication science: where do we go from here? Trends in Ecology 
\& Evolution, 2009, 24(4), 201-207. http://dx.doi. org/10.1016/j.tree.2008.11.009. PMid:19246117.

SMITH, V.H. Eutrophication of freshwater and marine ecosystems: a global problem. Environmental Science and Pollution Research International, 2003, 10(2), 126139. http://dx.doi.org/10.1065/espr2002.12.142. PMid:12729046.

SOLORZANO, L. Determination of ammonia in natural waters by the phenolhypochlorite method. Limnology and Oceanography, 1969, 14, 799-801. http://dx.doi.org/10.4319/lo.1969.14.5.0799.

SOUZA, M.L., PELLEGRINI, B.G. and FERRAGUT, C. Periphytic algal community structure in relation to seasonal variation and macrophyte richness in a shallow tropical reservoir. Hydrobiologia, 2015, 755, 183-196. http://dx.doi.org/10.1007/s10750-0152232-2.

STRICKLAND, J.D. and PARSONS, T.R. A manual of sea water analysis. Bulletin - Fisheries Research Board of Canada, 1960, 125, 1-185.

UTERMÖHL, H. Zur Vervolkomnung der quantitative Phytoplankton-Methodik. Mitteilungen der Internationale Vereinigung für Theoretische und Angewandte Limnologie, 1958, 9, 1-38.
VADEBONCOEUR, Y. and STEINMAN, D. Periphyton Function in Lake Ecosystems. The Scientific World Journal, 2002, 2, 1449-1468. http:// dx.doi.org/10.1100/tsw.2002.294. PMid:12805932.

VALDERRAMA, G.C. The simultaneous analysis of total nitrogen and total phosphorus in natural waters. Marine Chemistry, 1981, 10(2), 109-122. http:// dx.doi.org/10.1016/0304-4203(81)90027-X.

VAN DAM, H., MERTENS, A. and SINKELDAM, J. A coded checklist and ecological indicator values of freshwater diatoms from the Netherlands. Netherlands Journal of Aquatic Ecology, 1994, 28, 117-133. http:// dx.doi.org/10.1007/BF02334251.

VAN DER HOEK, C., MANN, D.G. and JAHNS, H.M. Algae: an introduction to phycology. Cambridge: Cambridge University Press, 1997.

VICTORINO, V.I.P. Uma visão histórica dos recursos hídricos na cidade de São Paulo. Revista Brasileira de Recursos Hidricos, 2002, 7(1), 51-68. http://dx.doi. org/10.21168/rbrh.v7n1.p51-68.

Received: 14 August 2016 Accepted: 02 December 2016 


\section{Acta Limnologica Brasiliensia}

\section{Erratum}

In the article "Structural changes of the phytoplankton and epiphyton in an urban hypereutrophic reservoir”, DOI: http://dx.doi.org/10.1590/S2179-975X5716, published in Acta Limnologica Brasiliensia, 2016, vol. 28, e29:

Where it reads:
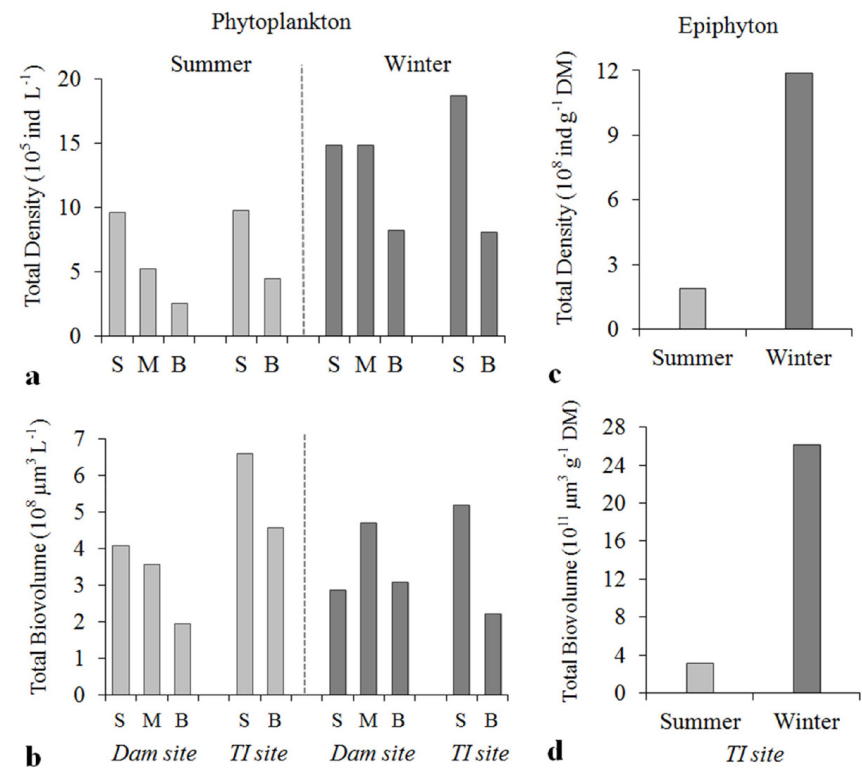

It should be read:
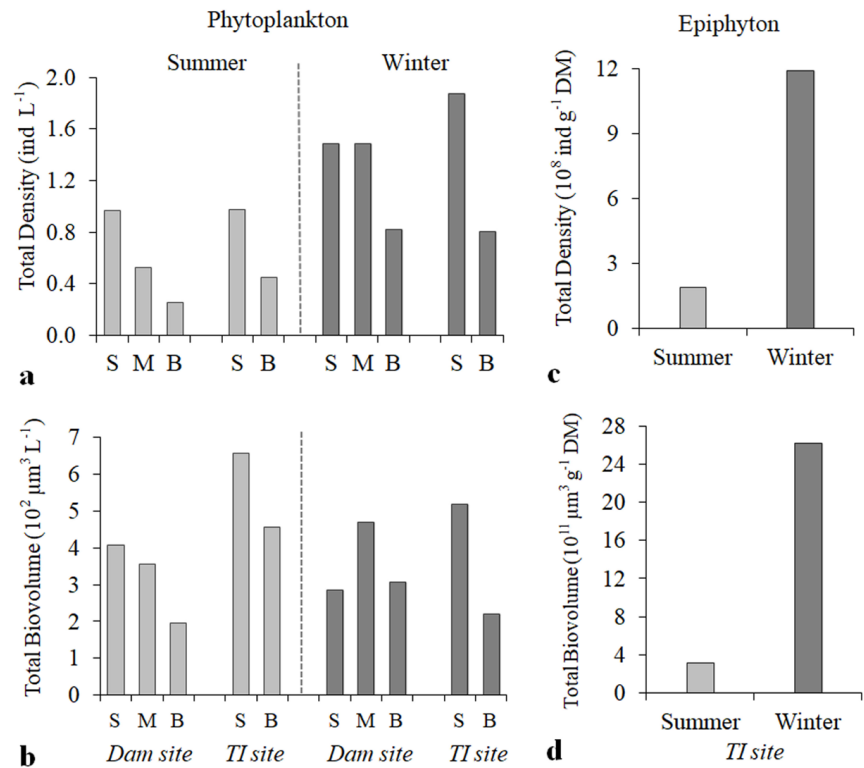